\title{
Macroeconomic Determinants of Under-Five Mortality Rate in Nigeria
}

\author{
Kehinde Kabir Agbatogun ${ }^{1^{*}}$, Olaide Sekinat Opeloyeru² \\ ${ }^{*}$ Corresponding author
}

\begin{abstract}
This paper examined the macroeconomic determinants of under-five mortality rate in Nigeria between 1980 and 2017. The study predicts by using the Grossman analytical framework rooted in the human capital development theory. A macro-econometric model is incorporating significant macroeconomic variables in explaining under-five mortality health outcomes. This research uses the ARDL bound test estimation technique that took into consideration the error correction mechanism. Tests of the model's reliability carry out using unit root and cointegration tests. The influences of government health expenditure were significant. However, both immunization initiatives and health workers exerted an insignificant positive influence on the under-five mortality rate. Thus, the study recommends policies targeted to improve the Nigerian health system in terms of creating an awareness relating to the service delivery and human capital development of the professionals in the sector to avert brain drain syndrome in the country.
\end{abstract}

Keywords: under-five mortality, per capita income, macroeconomic, literacy rate, government health expenditure

\begin{abstract}
Abstrak
Makalah ini meneliti faktor-faktor penentu ekonomi makro dari angka kematian balita di Nigeria antara tahun 1980 dan 2017. Penelitian ini didasarkan pada kerangka kerja analitis Grossman yang berakar pada teori pengembangan sumber daya manusia. Model makro-ekonometrik menggabungkan variabel makroekonomi utama dalam menjelaskan hasil kesehatan kematian balita. Teknik estimasi tes terikat ARDL yang mempertimbangkan mekanisme koreksi kesalahan digunakan. Pengujian reliabilitas model dilakukan dengan menggunakan unit root dan uji ko-integrasi. Pengaruh pengeluaran kesehatan pemerintah adalah signifikan, namun inisiatif imunisasi dan petugas kesehatan memberikan pengaruh positif yang tidak signifikan terhadap angka kematian balita. Dengan demikian, studi ini merekomendasikan kebijakan yang ditargetkan untuk meningkatkan sistem kesehatan Nigeria baik dalam hal penciptaan kesadaran yang berkaitan dengan pemberian layanan dan pengembangan sumber daya manusia dari para profesional di sektor ini.
\end{abstract}

Kata Kunci: kematian dibawah usia lima tahun, pendapatan per kapita, makroekonomi, tingkat literasi, pengeluaran pemerintah untuk kesehatan

JEL Classification: J11, J13

\section{How to Cite:}

Agbatogun, K. K., \& Opeloyeru, O. K. (2020). Macroeconomic Determinants of Under-Five Mortality Rate in Nigeria. Signifikan: Jurnal Ilmu Ekonomi, 9(2), 177-186. doi: http://doi.org/10.15408/sjie.v9i2.13751. 


\section{Introduction}

Despite the promise of health for all by the year 2000 in the 1990s, through Millennium Development Goals (MGDs) and later emphasized in Vision 20: 2020 and Sustainable Development Goals (SDGs), this lofty goal is yet to be realized in terms of reduction in under-five mortality rate, which is the death of infants and children under the age of five, in Sub-Saharan African (SSA) countries which Nigeria is inclusive. Many regions in SSA made little progress towards attaining the millennium development goal 4 (MDG-4) to reduce the global under-five mortality rate (U5MR) by two-thirds between 1990 and 2015.

The global under-five mortality rate has declined by half from 91 deaths per 1,000 live births in 1990 to 43 deaths per 1,000 live births in 2015. The World Health Organization (WHO) has estimated an average yearly rate of decline for under-five mortality from about 4\% per annum from 1990 - 2000 to approximately 2\% as of 2000 - 2015 (Global Health Observatory, 2017). However, the improvement was not enough to meet the Millennium Development Goal 4 (MDG-4) targeted at reducing child mortality, especially in the SubSahara region, where there has been an age-long prevalence of under-five mortality, despite increasing health interventions in the region. Out of 194 countries, along with Somalia, Angola, Central African Republic, Mali, Sierra Leone, and Chad, Nigeria is among the seven outliers African countries, with the highest risk of under-five mortality rates, jointly accounting for about one-fifth ( 1.1 million out of 5.9 million) of under-five mortality worldwide (Liu et al., 2016).

Nigeria has failed to make significant progress in curbing the rising rate of under-five mortality as statistics revealed that up to $20 \%$ of child death among the under-five in subSaharan Africa still occur in Nigeria. Also, the Multiple Indicator Cluster Survey (MICS, 2016/17) report indicated that the under-five mortality rate in Nigeria increased from 138 per 1,000 live births in 2007 to 158 per 1,000 live births in 2011 sky-rocketed to 203 per 1000 live birth in 2017. This fact is suggestive that one out of five births dies before their fifth year in Nigeria. (National Bureau of Statistics (NBS), 2012; MICS, 2016/17).

The relationship between macroeconomic factors and health status, which underfive mortality rate (U5MR) is a subset, are themselves often bi-directional, for instance, low income leads to poor health, and poor health leads to low income (Judge \& Peterson, 2001). GDP per capita has also found to be a significant determinant of infant mortality health status (Filmer \& Pritchet, 1997). Higher GDP per capita (income) can improve life expectancy because it facilitates access to health care, education, food, and housing, all of which contribute to better health outcomes. Thus, Grossman (1972a; 1972b and 2004) formed the framework of this study defines health as a durable capital stock inherited and depreciated over time. It is an endogenous variable that people can improve through investment in medical care, diet, and exercise. As income decreases, it will increase the rate of poor health (Kawachi \& Kennedy, 1997; Hurley et al., 2020). The relationship in question exists for all the usual measures of health outcomes, including morbidity, perceived health status, and mortality (Kaplan et al., 1996; Ren et al., 2019). 
The level of the educational level has shown to play an essential role in determining health behaviors and health outcomes. Poorly educated people die at a higher rate than highly educated people (Mackenbach, 2008; Östergren, 2018), and generally, people with the worst health status have low education levels. This condition consequently affects their children. Literature has shown that literacy rate positively affects health outcomes. For instance, illiterate or semiliterate patients usually had trouble understanding instructions prescriptions on drug bottles, appointment slips, medical, educational brochures, and consent forms. (Schillinger et al., 2002; Jourmand et al., 2008; Singh \& Aiken, 2017; Du et al., 2018). Low literacy level coincides with poverty, malnutrition, ill-health, and high infant and child mortality (Blunch, 2013). Many studies have found that people with low literacy skills cannot function well in a health care environment. Similarly, the mother's education was a significant factor in determining the variability of the under-five mortality rate in African countries (Van Malderen et al., 2019). The proportion of children whose mother had at least a primary education level varied from $6 \%$ to $86 \%$ and this variation strongly influenced the under-five mortality rate in these countries.

Critical questions for policy and health sector strategy are: how far has public expenditure been instrumental to bringing about the progress in children's health status in developing countries over the last five decades, and which programs have been particularly useful? Early studies by Musgrave (1996) find no evidence that total spending on health has any impact on child mortality. Filmer \& Pritchet (1997) present empirical evidence that suggests that public spending on health is not the dominant driver of the under-five mortality outcome.

A World Bank report included an analysis of infant mortality and health expenditure using panel data for the Indian states between 1980 and 1999. This study found no effect of health expenditure on mortality rate. However, using data for 50 developing and transition countries observed in 1994, Gupta et al., (2003) found that health expenditure reduces childhood mortality and under-five mortality rate in the selected countries. Similarly, government spending on health is also an essential factor in various health indicators; the under-five mortality rate inclusive (Bokhari et al., 2007; McCullough, 2017). More specifically, an increase in the share of public expenditure allocated to health spending has associated with a reduction in mortality rate.

On the relationship between GDP per capita income and health outcomes, the overwhelming conclusion is a linear relationship. Pritchett \& Summers (1996) note, "wealthier nations are healthier nations" and "gains from rapid Economic Growth flow into Health gains." The idea that income may have a positive effect on health outcomes is plausible, for the simple reason that higher-income permits households to spend more on the personal health of the family, which in turn, improves the household's health. Under this scenario, the country's income level on the country's health outcome will depend on country-specific factors such as education, nutrition, and factors that affect the delivery of health-related services. Asiedu et al. (2015) also found an inverse relationship between GDP per capita and the under-five mortality rate in the examined countries.

Over the years, the Nigerian government has been in severe pursuit of programs and policies that will ensure improvement and stability in the health status of her citizens. However, the continued downward spiral movement of the under-five mortality 
improvement rate in Nigeria seems to put a question mark on the effective implementation of the health policies so far instituted. These have resulted in a lack of access to primary healthcare packages by a large proportion of the population.

Thus, recognizing the significance of the various submissions in the reviewed studies, the study identified a research gap of non-inclusion of the impact of immunization on the factors affecting the under-five mortality rate in the literature. Consequently, the study's contribution to knowledge is the inclusion of immunization impact on the health status of under-five children. Purposefully, the study intends to fill the gap in the literature by analyzing the impact of its provision for an increase in the stock of health through immunization initiatives on under-five children, along with other macroeconomic factors identified as determinants of under-five mortality rate in Nigeria, using a time-series data sourced from world development indicators from the period of 1980 to 2017.

\section{Methods}

The method employed in this study is the Error Correction Model (ECM) of data analysis on time series data relating to Nigeria between 1980 and 2017. The pre-data analysis carries using unit root and cointegration tests. Within the context of the theoretical consideration, determinants of Under-Five Mortality Rate (U5MR) status in Nigeria and the literature review, we specify a model expressing the functional relationship between Under-Five Mortality Rate (U5MR) (dependent variable) and other explanatory variables of concern: literacy rate, government expenditure in the health sector, total immunization rate and total health workers in Nigeria. The specification of the model is suitable for quantifying the impact of the determinants on the Under-Five Mortality Rate (U5MR) status in Nigeria that follows the related empirical work of Fayissa \& Gutema (2005). Thus, the model for the estimation in this study is as follows:

$$
\text { InU5MR }_{t}=\alpha_{0}+\alpha_{1} \text { InLR }_{t}+\alpha_{2} \text { InGHEt }+\alpha_{4} \text { InIMMt }+\alpha_{5} \text { InGPC }_{t}+\mu_{t}
$$

Granger (1988) demonstrates that causal relations among variables can examine within the framework of the ARDL Error Correction Mechanism (ECM), with cointegrated variables. While the lagged terms' coefficients capture the short-run dynamics, the error correction term (ECT) contains the information of long-run causality. Significance of lagged explanatory variable depicts short-run causality, while a negative and statistically significant ECT is assumed to signify long-run causality. The short-run causality is determining from the following ARDL model:

$$
\Delta \mathrm{U} \mathrm{MR}_{\mathrm{t}}=\psi_{0}+\psi_{1} \Delta \mathrm{LR}_{\mathrm{t}-\mathrm{i}}+\psi_{2} \Delta \mathrm{GHE}_{\mathrm{t}-\mathrm{i}}+\psi_{3} \Delta \mathrm{IMM}_{\mathrm{t}-\mathrm{i}}+\psi_{4} \Delta \mathrm{HW}_{\mathrm{t}-\mathrm{i}}+\psi_{5} \Delta \mathrm{GPC}_{\mathrm{t}-\mathrm{i}} \eta \mathrm{ECM}_{\mathrm{t}-1}+\mu_{\mathrm{t}}
$$

Where:

$\mathrm{U}_{5} \mathrm{MR}_{\mathrm{t}}=$ Under-five mortality rate (Proxy for health status)

$\mathrm{LR}_{\mathrm{t}} \quad=$ Literacy rate

$\mathrm{GHE}_{\mathrm{t}} \quad=$ Total government health expenditure

$\mathrm{HW}_{\mathrm{t}} \quad=$ Total health workers

$\mathrm{IMM}_{\mathrm{t}}=$ Total immunisation rate $(\mathrm{BCG}+\mathrm{DPT}+\mathrm{HepB} 3+$ measles + Pol3 $)$

$\mathrm{GPC}_{\mathrm{t}}=$ GDP per capita 


\section{Results and Discussion}

Table 1 presents the results of the unit root test. Under Augmented Dickey-Fuller (ADF), Dickey-Fuller (DF), and Phillip Perron (PP) criteria, all the variables were significant at a $1 \%$ level of significance except $\ln U 5 \mathrm{MR}$ that display significance at $10 \%$. While under the DF criterion, only InLR and InHW were not significant, others were significant at a $5 \%$ level of significance. However, in all the instances, the variables were stationary at first difference $\{I(I)\}$, where the significance of the variables establish.

Table 1. Unit Root Test

\begin{tabular}{lccccccccc}
\hline & \multicolumn{3}{c}{ ADF } & \multicolumn{3}{c}{ DF } & \multicolumn{3}{c}{ PP } \\
\cline { 2 - 10 } Variables & ADF & $\begin{array}{c}\text { Critical } \\
\text { Value 5\% }\end{array}$ & Remarks & $\begin{array}{c}\text { DF-GLS } \\
\text { test }\end{array}$ & $\begin{array}{c}\text { Critical } \\
\text { Value 5\% }\end{array}$ & Remarks & PP & $\begin{array}{c}\text { Critical } \\
\text { Value 5\% }\end{array}$ & Remarks \\
\hline InLR & $-7.265^{*}$ & -2.960 & $\mathrm{~S}$ & -1.0356 & -1.953 & $\mathrm{NS}$ & $-15.483^{*}$ & -2.951 & $\mathrm{~S}$ \\
InGHE & $-6.417^{*}$ & -2.951 & $\mathrm{~S}$ & $-5.399^{*}$ & -1.951 & $\mathrm{~S}$ & $-6.377^{*}$ & -2.951 & $\mathrm{~S}$ \\
InHW & $-9.749^{*}$ & -2.954 & $\mathrm{~S}$ & -1.068 & -1.952 & $\mathrm{NS}$ & $-15.315^{*}$ & -2.951 & $\mathrm{~S}$ \\
InIMM & $-3.808^{*}$ & -2.951 & $\mathrm{~S}$ & $-2.867^{*}$ & -1.951 & $\mathrm{~S}$ & $-3.835^{*}$ & -2.951 & $\mathrm{~S}$ \\
InU5MR & $-2.952^{* * *}$ & -2.651 & $\mathrm{~S}$ & $-2.694^{*}$ & -1.951 & $\mathrm{~S}$ & $-2.723^{* * *}$ & -2.614 & $\mathrm{~S}$ \\
InGPC & $-3.234^{*}$ & -2.341 & $\mathrm{~S}$ & $-1.930^{*}$ & -1.900 & $\mathrm{~S}$ & $-4.287^{*}$ & -2.923 & $\mathrm{~S}$ \\
\hline
\end{tabular}

Note: ${ }^{*}$ Significant at $1 \% ;{ }^{* *}$ Significant at $5 \% ;{ }^{* * *}$ Significant at $10 \%$

Source: Author's Computation (2019)

As shown in Table 2, the long-run model result revealed that only health workers (InHW) failed to conform to the a priori expectations in the model while others were consistent with the theoretical standpoints. The lack of conformity of the health workers (InHW) in the model implies that health workers had no contribution to the reduction of under-five mortality rate in Nigeria, contrary to the findings in the literature (Christopher, 2018). The deplorable state of health workers conditions could directly associate with the high degree of brain drain of experienced medical professionals whose specialization is related to pediatric and maternal health in Nigeria, leading to an increase in the number of deaths of children in the country.

Table 2. ARDL Long Run Coefficients Results

\begin{tabular}{ccccc}
\hline Variables & Coefficient & Std. Error & t-Statistic & Prob. \\
\hline InGHE & -0.113 & 0.023 & -4.910 & 0.000 \\
InIMM & -0.045 & 0.047 & -0.938 & 0.358 \\
InHW & 0.358 & 0.204 & 1.750 & 0.094 \\
InLR & -0.058 & 0.089 & -0.656 & 0.519 \\
InGPC & -0.551 & 0.288 & -0.522 & 0.136 \\
C & 7.204 & 0.689 & 10.460 & 0.000 \\
\hline
\end{tabular}

Source: Author's Computation (2019) 
However, among those that showed consistency with the a priori signs, only government health expenditure (InGHE) was significant at a $1 \%$ level of significance. The economic implication is that government health expenditure (InGHE), literacy rate (InLR), Immunisation rate (InIMM) and GDP per capita (InGPC) made contributions to the reduction of under-five mortality in Nigeria, but statistically, only government health expenditure made a significant impact towards the reduction of under-five mortality rate in Nigeria, which is consistent with the findings in the literature (Gupta et al., 1999; 2002). Spending on both primary and secondary healthcare sectors, which manifested in the construction of new health care units, acquiring medical equipment and materials, implementing various health programs, and training health personnel in the industry immensely contributed to the reduction of under-five mortality in Nigeria.

Consistency with findings in the literature (Mackenbach, 2008; Schillinger et al., 2002; Shaw et al., 2005 and Van Malderen et al. 2019), literacy rates impacted the variability of under-five mortality rate in Nigeria. Lack of primary education starts manifestation in health care delivery from the point of initiation of contact with the health care providers by the health care seekers (patients) to the end of understanding the prescription and administering of prescribed drugs.

Though GDP per capita income and immunization rate impacted the variability of under-five mortality in Nigeria, they both failed to contribute significantly to the reduction of the under-five death rate. The positive impact of GDP per capita agreed with earlier studies such as Pritchett \& Summers (1996) and Asiedu et al. (2015). The relatively low average income among the country's populace coupled with the high cost of healthcare delivery could be the limiting factor of the insignificant impact of GDP per capita on the reduction of the under-five mortality rate in Nigeria. This instance could also be directly related to the fact that a more significant proportion of Nigerians patronize private health care providers, and most of them are not on governmentsubsidized health care programs such as National Health Insurance Scheme (NHIS). Besides, most health care programs sponsored by the Nigerian government lack adequate rural coverage due to inadequate sensitization and adversely affect health outcomes in the remote areas. Specifically, many immunization program initiatives neglect rural areas but concentrate mostly on the urban areas, and cumulatively failed to reduce under-five mortality in the country significantly.

In Table 3, the ARDL result indicates that all the variables are cointegrated, and the one-year lag of the variables has effects on the current values. The results in the table below show that except (dlnHW) and (dInGPC), which are two-year lag significant, other variables- $(\mathrm{d} \ln L E),(\mathrm{d} \ln I M M)$, and $(\mathrm{d} \ln G H E)$ are not significant. The result in the current year estimate is also similar in the one-year lag estimate of the equation. The error correction term (ECT) is significant, confirming the existence of a short-run relationship in the model and also reveals that the speed of adjustment from short-run disequilibrium to long-run equilibrium is $14.9 \%$. As shown in Figure 1, the stability test shows that the variables are stable using the CUSUM test. 
Table 3. ARDL Cointegration Short Run Results

\begin{tabular}{|c|c|c|c|}
\hline Variables & Coefficient & Std. Error & t-Statistic \\
\hline $\mathrm{D}(\mathrm{InGHE})$ & -0.003 & 0.006 & -0.549 \\
\hline $\mathrm{D}(\ln G H E(-1))$ & 0.012 & 0.006 & 1.951 \\
\hline $\mathrm{D}(\operatorname{InIMM})$ & -0.007 & 0.007 & -0.978 \\
\hline $\mathrm{D}(\mathrm{InHW})$ & 0.007 & 0.012 & 0.638 \\
\hline $\mathrm{D}(\operatorname{InHW}(-1))$ & -0.015 & 0.009 & -1.628 \\
\hline $\mathrm{D}(\operatorname{InHW}(-2))$ & $-0.023^{*}$ & 0.007 & -3.141 \\
\hline$D(\operatorname{lnLR})$ & -0.009 & 0.014 & -0.612 \\
\hline $\mathrm{D}(\operatorname{lnGPC})$ & -0.026 & 0.051 & -0.512 \\
\hline$D(\ln G P C(-1))$ & 0.004 & 0.060 & 0.065 \\
\hline$D(\ln G P C(-2))$ & $0.007^{* *}$ & 0.049 & 0.134 \\
\hline CointEq(-1) & $-0.149^{*}$ & 0.038 & -3.884 \\
\hline
\end{tabular}

Note: * Significant at $1 \% ;{ }^{* *}$ Significant at $5 \% ;{ }^{* * *}$ Significant at $10 \%$

Source: Author's Computation (2019)

Figure 1. Stability Test on Long-Run Relationship

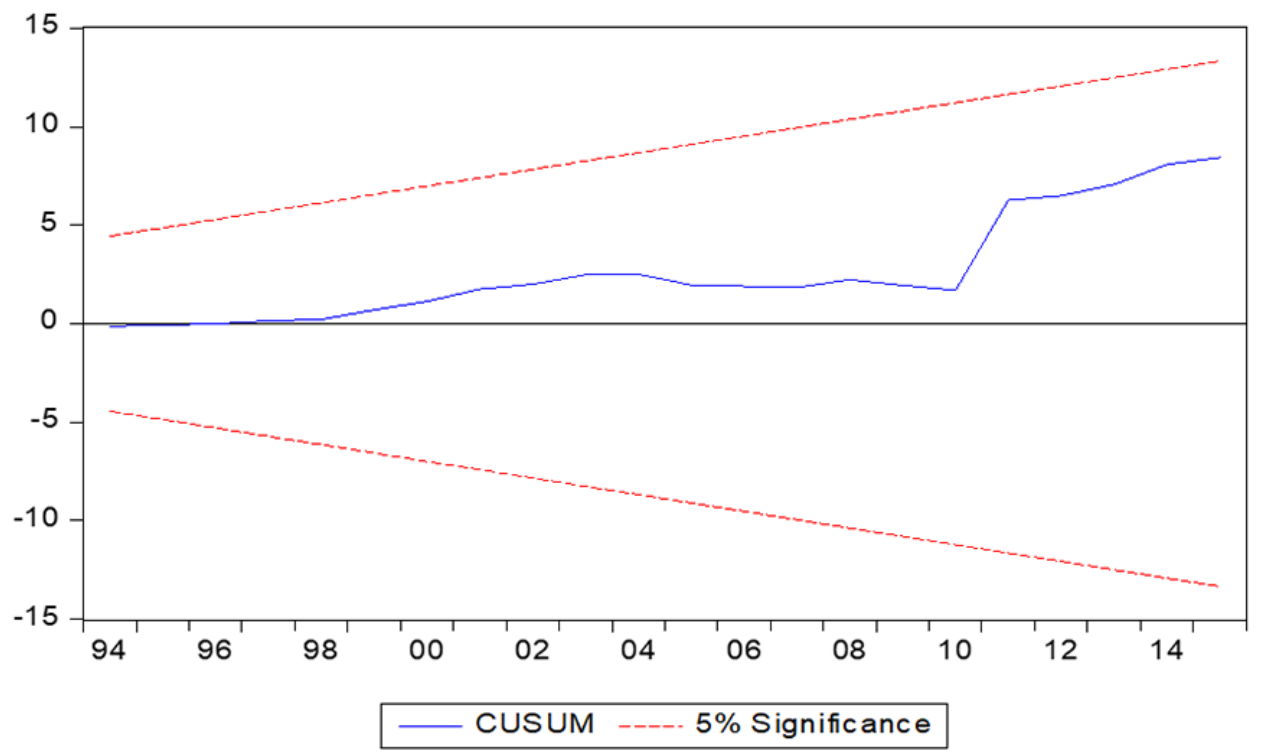

Source: Author's Computation (2019)

In Table 4, we compared the calculated F-statistic with critical values from Narayan (2005) generated for small sample sizes of between 30 and 80 observations. One set assumes that all variables in the model are I(0), and the other set assumes they are all I (1). If the calculated F-statistic exceeds the upper critical bounds value, then the $\mathrm{H} 0$ is rejected. If the F-statistic falls within the bounds, then the test is inconclusive. Lastly, if the F-statistic falls below the lower critical bounds value, it implies that there is no cointegration. From the table, we conclude that there is a long-run relationship between the variables as the Cal. F-Statistic 
(12.40) is higher than all the critical bound value at all levels. Thus, the null hypothesis of no cointegration rejects in the models.

Table 4. Bounds Test on Long-Run Coefficients in the Unrestricted ECM

\begin{tabular}{|c|c|c|c|c|c|c|c|}
\hline \multicolumn{8}{|c|}{ BOUND TEST } \\
\hline \multirow{3}{*}{ Test Statistics } & \multirow{3}{*}{ Value } & \multicolumn{6}{|c|}{ Critical Bounds Value k=4 } \\
\hline & & \multicolumn{2}{|c|}{$10 \%$} & \multicolumn{2}{|c|}{$5 \%$} & \multicolumn{2}{|c|}{$1 \%$} \\
\hline & & $((10)$ & $\mathrm{I}(\mathrm{I}))$ & $((10)$ & $\mathrm{I}(\mathrm{I}))$ & $((I 0)$ & $I(I))$ \\
\hline F-stat & 12.40 & 2.45 & 3.52 & 2.86 & 4.01 & 3.74 & 5.06 \\
\hline
\end{tabular}

Source: Author's Computation (2019)

\section{Conclusion}

Contrary to the literature's findings, the empirical investigation reveals that GDP per capita trivially influences the under-five mortality rate in Nigeria. Literature has shown that high GDP per capita can improve the under-five mortality rate because it facilitates access to health care, education, food, and housing, all of which contribute to health outcomes. In Nigeria, income is not evenly distributed relative to other countries of the world, and as such, the high value of GDP per capita would not necessarily improve health status and standard of living in Nigeria. The facts can explain the insignificance of health workers in improving the under-five mortality rate that brain drain syndrome affects the quality of health workers in Nigeria. Meanwhile, immunization initiative programs should enhance the Nigerian health system plan to have a publicized and well-structured extension to the local areas to optimize the associated benefits of such programs.

In conclusion, it is evident that, like other developing countries of the world, for Nigeria to take a giant stride towards economic development, she needs to improve its citizens' health status. Thus, the study recommends policies that will increase the monitoring mechanism on public spending on the health sector, promote literacy rate, reduce the instances of braindrain rate and create awareness on various government health programs both in the rural and urban areas in the country.

\section{References}

Asiedu, E., Gaekwad, N.B., Nanivazo, M., Nkusu, M., \& Jin,Y. (2015). On the Impact of Income per Capita on Health Outcomes: Is Africa Different?. Retrieved on 10/02/2020 from https:/www.aeaweb.org/conference/2016/retrieve.php?pdfid=1019

Blunch, N-H. (2013) Staying Alive: Adult Literacy Programs and Child Mortality in Rural Ghana. World Development, 42, 114-126. https://doi.org/10.1016/j.worlddev.2012. 06.021.

Bokhari, F., Gai, Y., \& Gottret, P. (2007). Government Health Expenditures and Health Outcomes. Health Economics, 16(3), 257-273.

Christopher E. N. (2018). The Effects of Public Health Spending on Maternal Mortality in Nigeria. Journal of Economics and Sustainable Development, 9(20), 141-152. 
Du, S., Zhou, Y., Fu, C., Wang, Y., Du, X., \& Xie, R. (2018). Health Literacy and Health Outcomes in Hypertension: an Integrative Review. International Journal of Nursing Science, 5(3), 301-309. https://doi.org/10.1016/j.ijnss.2018.06.001.

Fayissa, B., \& Gutema, P. (2005). Determinants of Health Status in Sub-Sahara Africa. The American Economist. 49(2), 60 - 66.

Filmer, D., \& Pritchett, L. (1997). Child Mortality and Public Spending on Health: How Much Does Money Matter? World Bank Policy Research Working Paper No.1864 Washington: World Bank.

Global Health Observatory (GHO) data, 2017. Retrieved from: http:/www.who.int/gho/ child_health/mortality/mortality_under_five_text/en/.

Granger, C.W.J. (1988). Causality, Cointegration and Control. Journal of Economic Dynamics and Control, 12(3), 551-559.

Grossman, M. (1972a). The Demand for Health: A Theoretical and Empirical Investigation. New York: NBER Book.

Grossman, M. (1972b). On the Concept of Health of Health Capital and the Demand for Health. Journal of Political Economy, 80(2), 223-255.

Grossman, M. (2004). The Demand for Health, 30 Years later; a Very Personal Retrospective and Prospective Reflection. Journal of Health Economics, 23(4), 629-636.

Gupta, S., Verhoeven, M., \& Tiongson, E. (1999). Does Higher Government Spending Buy Better Results in Education and Health Care?. IMF Working Paper No. 99/21. Washington D.C: International Monetary Fund.

Gupta, S., Verhoeven, M., \& Tiongson, E. (2002). The Effectiveness of Government Spending on Education and Health Care in Developing and Transition Economies. European Journal of Political Economy, 18(4), 717-737.

Gupta, S., Verhoeven, M., \& Tiongson, E. (2003). Public Spending on Health Care and the Poor. Health Economics, 12, 685-96.

Hurley, J., Mentzakis, E., \& Walli-Attaei, M. (2020). Inequality Aversion in Income, Health, and Income-related Health. Journal of Health Economics, 70, 102276. https://doi. org/10.1016/j.jhealeco.2019.102276.

Jourmand, I., Andre, C., Nicq, C., \& Chatal, O. (2008). Health Status Determinants: Lifestyle, Environment, Health Care Resources and Efficiency. OECD Economic Department Working Papers, No. 627, OECD.

Judge, K., \& Peterson, L. (2001). Poverty, Income Inequality and Health. New Zealand Treasury Working Paper, no 01/29, New Zealand Government, The Treasury, Wellington.

Kaplan, G., Pamuk, E., Lynch, J., Cohen, R., \& Balfour, A. (1996). Inequality in Income and Mortality in the United States: Analysis of Mortality and Potential Pathways. British Medical Journal, 312, 999-1003.

Kawachi, I., \& Kennedy, B. (1997). The Relationship of Income Inequality to Mortality; Does the Choice of Indicator Matter?. Social Science and Medicine, 45(7), 1121-27. 
Liu, L., Oza, S., Hogan, D., Chu, Y., Perin, J., \& Zhu, J. (2016). Global, Regional, and National Causes of Under-5 Mortality in 2000- 15: an Updated Systematic Analysis with Implications for the Sustainable Development Goals. Lancet, 388(10063), 30273035. https://doi.org/10.1016/S0140-6736(16)31593-8.

Mackenbach, J. P. (2008). Socioeconomic Inequalities in Health in 22 European Countries. New England Journal of Medicine, 358(23), 2468-2481.

McCullough, J. M. (2017). Local Health and Social Services Expenditures: an Empirical Typology of Local Government Spending. Preventive Medicine, 105. 66-72. https:// doi.org/10.1016/j.ypmed.2017.08.018.

Musgrave, R. A. (1996). Public Finance and Finanzwissenschaft Traditions Compared. Finanzarchiv, 53(2), 145-193.

Narayan, P. K. (2005). The saving and investment Nexus for China: Evidence from cointegration tests. Applied Economics, 37(17), 1979-1990.

Östergren, O. (2018). Educational Inequalities in Mortality are Larger at Low Levels of Income: a Register-based Study on Premature Mortality among 2.3 million Swedes, 2006-2009. SSM-Population Health, 5, 122-128. https://doi.org/10.1016/j.ssmph. 2018.05.008.

Pritchett, 1., \& Summers, L. H. (1996). Wealthier is Healthier. The Journal of Human Resources, 31(4), 841-868.

Ren, Y., Li, H., \& Wang, X. (2019). Family Income and Nutrition-related Health: Evidence from Food Consumption in China. Social Science and Medicine, 232, 58-76. https:// doi.org/10.1016/j.socscimed.2019.04.016.

Schillinger D., Grumbach K., Piette J., Wang F., Osmond D., Daher C., Palacios J., Sullivan G. D., \&Bindman, A.B. (2002). Association of Health Literacy with Diabetes Outcomes. JAMA, 288(4), 475-482.

Shaw, J., Williams H., \& Ronald, V. (2005). The Determinants of Life expectancy: An Analysis of the OECD Health Data. Southern Economic Journal, 71(4), 768-783.

Singh, S. G., \& Aiken, J. (2017). The Effect of Health Literacy Level on Health Outcomes in Patients with Diabetes at a Type V Health Centre in Western Jamaica. International Journal of Nursing Science, 4(3), 266-270. https://doi.org/10.1016/j.ijnss.2017.06.004.

Van Malderen C., Amouzou A., Barros A. J. D., Masquelier B., Van Oyen H., \& Speybroeck, N. (2019). Socioeconomic Factors Contributing to Under-Five Mortality in SubSaharan Africa: a Decomposition Analysis. BMC Public Health, 19(760), 1-19. 